\title{
Effect of Planting Density and Nutrient Requirement on Growth and Development of Banana cv. Quintal Nendran (AAB)
}

\author{
V. Sindhupriya ${ }^{1 *}$, J. Auxcilia ${ }^{2}$ and K. Soorianathasundaram ${ }^{1}$ \\ ${ }^{1}$ Department of Fruit Crops, Horticultural College and Research Institute, \\ Coimbatore, Tamil Nadu, India \\ ${ }^{2}$ Department of Horticulture, Horticultural College and Research Institute (Women), \\ Trichy, Tamil Nadu, India \\ *Corresponding author
}

\section{A B S T R A C T}

A field experiment was conducted at University Orchard, Horticultural College and Research Institute, Coimbatore to standardize the cropping density and nutrient requirement on growth and development of banana cv. Quintal Nendran (AAB) during

Keywords

Banana, Crop density, Fertigation, Quintal Nendran

Article Info

Accepted:

26 October 2018

Available Online:

10 November 2018 2015-17. The studies were carried out by planting banana suckers at three spacing levels viz., $\mathrm{S}_{1}-1.8 \times 1.8 \mathrm{~m}\left(3086\right.$ plants ha $\left.{ }^{-1}\right), \mathrm{S}_{2}-2.1 \times 2.1 \mathrm{~m}\left(2267\right.$ plants ha $\left.{ }^{-1}\right), \mathrm{S}_{3}-2.1 \times 2.4 \mathrm{~m}$ (1984 plants ha ${ }^{-1}$ ) with four fertigation levels viz., $\mathrm{F}_{1}-75$ per cent, $\mathrm{F}_{2}-100$ per cent, $\mathrm{F}_{3}$ 125 per cent and $\mathrm{F}_{4}-150$ per cent RDF. The results revealed that plant density and fertigation influenced growth and development of banana cv. Quintal Nendran. The lowest pseudostem height $(294.44$ and $300.86 \mathrm{~cm})$ at shooting stage was recorded in spacing $\left(\mathrm{S}_{3}\right)$, fertigation $\left(F_{1}\right)$ compared to other treatments. The lowest absolute growth rate (AGR) for pseudostem height $\left(0.843 \mathrm{~cm} \mathrm{day}^{-1}\right.$ and $\left.0.870 \mathrm{~cm} \mathrm{day}^{-1}\right)$ during 9 month after planting (MAP) to shooting stage was recorded in $\mathrm{S}_{3}$ spacing and $\mathrm{F}_{1}$ fertigation. The highest pseudostem girth $(68.48$ and $71.15 \mathrm{~cm})$ at shooting stage was recorded in spacing $\left(\mathrm{S}_{2}\right)$, fertigation $\left(\mathrm{F}_{3}\right)$ and their interaction $\left(\mathrm{S}_{3} \mathrm{~F}_{3}\right)$ treatment $(73.10 \mathrm{~cm})$. The highest absolute growth rate for pseudostem girth was recorded in wider spacing $\left(S_{2}\right.$ and $\left.S_{3}\right)$. The wider spacing $\left(\mathrm{S}_{3}\right)$ and higher level of fertigation $\left(\mathrm{F}_{4}\right)$ registered more number of suckers $(7.09$ and 6.90).

\section{Introduction}

Banana belongs to the genus Musa of the family Musaceae. Its cultivation is distributed throughout the warmer countries and is confined to regions between $30^{\circ} \mathrm{N}$ and $30^{\circ} \mathrm{S}$ of equator. Together, bananas and plantain, are the fourth most important food crop in the world after rice, wheat and maize (Salvador $e t$ al., 2007). Banana and plantain are fruit crops of great socio-economic significance as they serve as staple food for many millions of people across the tropics and sub tropics. Globally, bananas are grown in more than 135 countries across the world with an annual production of over 144 million tonnes (NHB, 2017). Quintal Nendran banana, considered as Giant Plantain, recorded higher plant height, pseudostem girth, days from shooting to harvest, crop duration and bunch weight. 
Quintal Nendran (AAB) is a popular variety in Kerala where it is relished as a fruit as well as used for processing. Commercial cultivation of Quintal Nendran has picked up rapidly in Tamil Nadu in the recent past. On an average, it produces a bunch weighing $15-17 \mathrm{~kg}$ and the weight goes even up to $18-30 \mathrm{~kg}$ in a crop duration of 13-15 months. The number of hands per bunch varies from 7-10.

The planting distance adopted for banana varies throughout the world (Nankinga et al., 2005). High density planting is gaining importance due to shrinkage of cultivated land. It provides economic use of land, efficient utilization of solar energy, water, fertilizer, pesticides and ultimately leads to increased yield.HDP has been successfully adopted in many fruit crops. HDP as one of the technologies of hi- tech banana cultivation, gives high yield and profit. HDP can significantly increase the yield per unit area as the plants are planted closer compared to traditional planting methods (Mahalakshmi, 2000).

Water and nutrients are the key important factors in banana cultivation and research experiments have clearly demonstrated that for higher productivity of banana, application of recommended doses of essential nutrients at appropriate crop growth stage is necessary. Therefore, it is essential to apply the recommended doses of nutrients at appropriate growth stages by efficient method of application in order to increase the productivity and profitability. Hence, the present study was undertaken to standardize crop density and fertigation for banana $\mathrm{cv}$. Quintal Nendran for maximizing the quality and yield under tropical field conditions.

\section{Materials and Methods}

The study was conducted at University Orchard, Horticultural College and Research
Institute, Tamil Nadu Agricultural University, Coimbatore. The amount of fertilizer to be applied is calculated based on the fertilizer dose and split dose details recommended by TNAU. The suckers are planted at three different spacings viz., $1.8 \mathrm{~m} \mathrm{X} 1.8 \mathrm{~m}$ (S1) accommodating 3086 plants ha ${ }^{-1,} 2.1 \times 2.4 \mathrm{~m}$ (S2) accommodating 1984 plants $\mathrm{ha}^{-1}$ and $2.4 \mathrm{x}$ $2.4 \mathrm{~m}$ (S3) accommodating 1736 plants ha ${ }^{-1}$. The sub plot treatments include four fertigation levels viz., $\mathrm{F}_{1}-75$ per cent, $\mathrm{F}_{2}-100$ per cent, $F_{3}-125$ per cent and $F_{4}-150$ per cent RDF. Recommended dose of fertilizer for Nendran is 150:90:300 $\mathrm{g} \mathrm{plant}^{-1}$ year $^{-1}$. The treatments were arranged in a split plot design with twelve treatment combinations in three replications. The height of the pseudostem was measured from the base of the trunk to the axil of the youngest leaf at third month, fifth month, seventh month, ninth month and at shooting stage. The girth of the pseudostem was measured at $30 \mathrm{~cm}$ height from the ground level at third month, fifth month and at shooting stage. Sucker production was recorded from 5 MAP to harvesting stages. Absolute growth rate was estimated for pseudostem height and pseudostem girth by using the following formula,

Absolute growth rate of pseudostem height $\left(\mathrm{cm} \mathrm{day}^{-1}\right)=\left[\mathrm{H}_{2}-\mathrm{H}_{1} / \mathrm{t}_{2}-\mathrm{t}_{1}\right]$

Where, $\mathrm{H}_{1}$ and $\mathrm{H}_{2}$ are pseudostem heights at times $t_{1}$ and $t_{2}$ respectively.

Absolute growth rate of pseudostem girth $\left(\operatorname{cmday}^{-1}\right)=\left[\mathrm{G}_{2}-\mathrm{G}_{1} / \mathrm{t}_{2}-\mathrm{t}_{1}\right]$

Where, $G_{1}$ and $G_{2}$ are pseudostem girths at times $t_{1}$ and $t_{2}$ respectively.

\section{Results and Discussion}

Pseudostem height is an important morphological parameter related to growth and development of the crop. Growth involves 
both cell growth and development. Cell growth and development is a process consisting of cell division, cell enlargement and cell differentiation. In the present study it can be observed that under different plant density and fertigation levels, the vegetative growth in terms of pseudostem height and girth increased with age of the crop up to shooting. Further, rapid rate of increase in pseudostem height and girth was observed between $5^{\text {th }}$ to $9^{\text {th }}$ MAP. Thereafter, the pseudostem height and girth had slowed down from $9^{\text {th }}$ MAP to shooting.

There were significant differences in pseudostem height due to spacing and fertigation levels at shooting stage (Table 1). In spacing levels $\mathrm{S}_{3}$ recorded lowest pseudostem height $(294.44 \mathrm{~cm})$, which was on par with $\mathrm{S}_{2}(302.46 \mathrm{~cm})$ and highest pseudostem height was recorded in $S_{1}$ $(321.75 \mathrm{~cm})$. The lowest pseudostem height was registered in $F_{1}(307.41 \mathrm{~cm})$. The highest height of the pseudostem $(312.19 \mathrm{~cm})$ was noticed in $F_{3}$, which was on par with $F_{4}$ $(307.98 \mathrm{~cm})$ and significantly superior over $F_{1}$ and $F_{2}(303.82 \mathrm{~cm})$. The interactions between spacing and fertigation levels were found nonsignificant. The highest pseudostem height in closer planting might be due to natural shading of plants resulting in competitive growth rate to intercept the light and also due to more availability of fertilizers, compared to other treatments. Similar results were also recorded by Athani et al., (2009), Sarrwy et al., (2012) and Naik (2016).

Increase in girth is a desirable factor as far as banana is concerned which has a close bearing on yield, anchorage as well as production of more roots as against the pseudostem height, which beyond certain limit is associated with more of negative influence such as susceptibility to wind and requirement of high propping cost etc., The variations in pseudosterm girth due to different levels of planting density and fertigation are tabulated in the table 2. The pseudostem girth at shooting stage due to spacing and fertigation differed significantly. The pseudostem girth at shooting stage due to spacing and fertigation differed significantly. The highest pseudostem girth $(69.86 \mathrm{~cm})$ was recorded in $\mathrm{S}_{3}$, which was on par with $S_{2}(68.98 \mathrm{~cm})$. The lowest pseudostem girth is registered in treatment $S_{1}$ $(67.17 \mathrm{~cm})$. The fertigation treatments differed significantly in pseudostem girth. In fertigation levels the highest pseudostem girth $(72.15 \mathrm{~cm})$ was recorded in $\mathrm{F}_{3}$, which was on par with $\mathrm{F}_{4}(70.84 \mathrm{~cm})$, followed by $\mathrm{F}_{2}(68.59$ $\mathrm{cm})$, while $F_{1}(63.10 \mathrm{~cm})$ registered lowest pseudostem girth. The interaction effects not differed significantly. The highest pseudostem girth in wider spacing $\left(S_{2}\right.$ and $\left.S_{3}\right)$ at highest level of fertigation $\left(\mathrm{F}_{3}\right.$ and $\left.\mathrm{F}_{4}\right)$ might be due to reduced pseudostem height, which led to more increase in stem girth due to more availability of nutrients compared to other treatments. The decrease in girth in closer spacing $\left(S_{1}\right)$ was due to increase in pseudostem height of the plant as a resulted of diversion of assimilates to increase in heights at the expense of girth.

Pseudostem girth increased at wider plant density indicating that pseudostem girth and height of banana are inversely proportional to each other. Increase in pseudostem girth and number of suckers per plant due to decrease in plant density may be due to the fact that, plants faced less competition for moisture and sunlight in wider spacing. The results of the present study are in accordance with the findings of Robinson Athani et al., (2009) in banana. Highest pseudostem girth was noted in $\mathrm{F}_{3}$. This might be due to the higher dose of nitrogen is responsible for the formation, growth and development of the cells and accelerated the synthesis of chlorophyll and amino acid which are associated with major photosynthesis process of plants, it causes an increase in the formation of meristematic tissues (Pralhad., 2014). 
Table.1 Effect of plant density and fertigation on pseudostem height $(\mathrm{cm})$ at different stages of growth of banana cv. Quintal Nendran (AAB)

\begin{tabular}{|c|c|c|c|c|c|c|c|c|c|c|c|c|}
\hline Stages & \multicolumn{4}{|c|}{3 MAP } & \multicolumn{4}{|c|}{5 MAP } & \multicolumn{4}{|c|}{7 MAP } \\
\hline $\begin{array}{c}\text { Spacing/ } \\
\text { Fertigation }\end{array}$ & $\mathbf{S}_{1}$ & $\mathbf{S}_{2}$ & $\mathbf{S}_{\mathbf{3}}$ & Mean & $\mathbf{S}_{1}$ & $\mathbf{S}_{2}$ & $\mathbf{S}_{\mathbf{3}}$ & Mean & $\mathbf{S}_{1}$ & $\mathbf{S}_{2}$ & $\mathbf{S}_{\mathbf{3}}$ & Mean \\
\hline$F_{1}$ & 89.43 & 87.46 & 89.56 & 88.82 & 137.49 & 133.04 & 130.15 & 133.56 & 191.79 & 181.94 & 178.39 & 184.04 \\
\hline $\mathrm{F}_{3}$ & 88.16 & 86.11 & 85.79 & 86.69 & 144.45 & 136.42 & 132.86 & 137.91 & 200.01 & 188.44 & 182.84 & 190.43 \\
\hline$F_{4}$ & 86.89 & 89.07 & 90.54 & 88.83 & 140.82 & 135.03 & 132.50 & 136.12 & 195.84 & 185.55 & 182.06 & 187.82 \\
\hline SEd & 1.50 & 1.21 & 2.36 & 2.09 & 1.19 & 1.50 & 2.54 & 2.59 & 2.60 & 2.12 & 4.11 & 3.67 \\
\hline $\begin{array}{l}C \mathrm{CD}=\mathrm{p} \\
(0.05)\end{array}$ & NS & NS & NS & NS & $3.30 * *$ & $3.15^{*}$ & NS & NS & $7.22 * *$ & $4.45^{*}$ & NS & NS \\
\hline
\end{tabular}

*Significant at $(\mathrm{P} \leq 0.05)$ NS: Not Significant

\begin{tabular}{|c|c|c|c|c|c|c|c|c|}
\hline Stages & \multicolumn{4}{|c|}{9 MAP } & \multicolumn{4}{|c|}{ At shooting } \\
\hline $\begin{array}{c}\text { Spacing/ } \\
\text { Fertigation } \\
\end{array}$ & $\mathbf{S}_{1}$ & $\mathbf{S}_{\mathbf{2}}$ & $\mathbf{S}_{\mathbf{3}}$ & Mean & $\mathbf{S}_{1}$ & $\mathbf{S}_{2}$ & $\mathbf{S}_{\mathbf{3}}$ & Mean \\
\hline$F_{1}$ & 259.59 & 246.74 & 239.59 & 248.64 & 315.81 & 297.26 & 289.51 & 300.86 \\
\hline $\mathbf{F}_{2}$ & 261.94 & 248.60 & 242.65 & 251.06 & 319.00 & 299.48 & 292.99 & 303.82 \\
\hline$F_{3}$ & 269.61 & 255.64 & 247.64 & 257.63 & 328.95 & 308.80 & 298.82 & 312.19 \\
\hline $\mathbf{F}_{4}$ & 264.84 & 252.15 & 245.66 & 254.22 & 323.22 & 304.29 & 296.42 & 307.98 \\
\hline Mean & 264.00 & 250.78 & 243.89 & & 321.75 & 302.46 & 294.44 & \\
\hline & $\mathbf{S}$ & $\mathbf{F}$ & $\mathrm{S}$ at $\mathrm{F}$ & $F$ at $S$ & $\mathbf{S}$ & $\mathbf{F}$ & $\mathbf{S}$ at $\mathbf{F}$ & $F$ at $S$ \\
\hline SEd & 1.16 & 3.11 & 4.81 & 5.38 & 2.56 & 3.22 & 5.48 & 5.58 \\
\hline$C D=p(0.05)$ & $3.24 *$ & $6.53 *$ & NS & NS & $7.12 *$ & $6.78 *$ & NS & NS \\
\hline
\end{tabular}

Spacing $\quad \mathrm{S}_{1}-1.8 \times 1.8 \mathrm{~m}\left(3,086\right.$ plants $\left.\mathrm{ha}^{-1}\right) ; \mathrm{S}_{2}-2.1 \times 2.1 \mathrm{~m}\left(2,267\right.$ plants ha $\left.{ }^{-1}\right) ; \mathrm{S}_{3}-2.4 \times 2.1 \mathrm{~m}\left(1,984\right.$ plants ha $\left.^{-1}\right)$

Fertigation $\mathrm{F}_{1}-75 \% \mathrm{RDF} ; \mathrm{F}_{2}-100 \% \mathrm{RDF} ; \mathrm{F}_{3}-125 \% \mathrm{RDF} ; \mathrm{F}_{4}-150 \%$ RDF (RDF - 150:90:300 g NPK)

Table.2 Effect of plant density and fertigation on pseudostem girth $(\mathrm{cm})$ at different stages of growth of banana $\mathrm{cv}$. 
Quintal Nendran (AAB)

\begin{tabular}{|c|c|c|c|c|c|c|c|c|c|c|c|c|}
\hline Stages & \multicolumn{4}{|c|}{3 MAP } & \multicolumn{4}{|c|}{5 MAP } & \multicolumn{4}{|c|}{7 MAP } \\
\hline $\begin{array}{c}\text { Spacing/ } \\
\text { Fertigation }\end{array}$ & $\mathbf{S}_{1}$ & $\mathbf{S}_{2}$ & $\mathbf{S}_{\mathbf{3}}$ & Mean & $\mathbf{S}_{1}$ & $\mathbf{S}_{2}$ & $\mathbf{S}_{\mathbf{3}}$ & Mean & $\mathbf{S}_{1}$ & $\mathbf{S}_{2}$ & $\mathbf{S}_{\mathbf{3}}$ & Mean \\
\hline $\mathrm{F}_{1}$ & 23.84 & 24.67 & 23.78 & 24.10 & 36.93 & 38.28 & 38.67 & 37.96 & 46.29 & 47.76 & 48.38 & 47.48 \\
\hline$F_{2}$ & 23.58 & 23.16 & 22.47 & 23.07 & 38.76 & 38.57 & 38.86 & 38.73 & 50.22 & 50.21 & 51.16 & 50.53 \\
\hline$\overline{F_{3}}$ & 24.39 & 25.22 & 23.33 & 24.31 & 39.78 & 40.71 & 40.90 & 40.46 & 52.00 & 53.19 & 53.45 & 52.88 \\
\hline $\mathbf{F}_{4}$ & 23.79 & 24.97 & 23.56 & 24.11 & 39.05 & 40.33 & 40.69 & 40.02 & 51.23 & 52.18 & 52.57 & 51.99 \\
\hline Mean & 23.90 & 24.51 & 23.29 & & 38.63 & 39.47 & 39.78 & & 49.94 & 50.84 & 51.39 & \\
\hline & $\mathbf{S}$ & $\mathbf{F}$ & $\mathrm{S}$ at $\mathrm{F}$ & $F$ at $S$ & $\mathbf{S}$ & $\mathbf{F}$ & $S$ at $F$ & $F$ at $S$ & $\mathbf{S}$ & $\mathbf{F}$ & S at $F$ & $F$ at $S$ \\
\hline SEd & 0.37 & 1.26 & 0.97 & 0.95 & 0.30 & 0.43 & 0.71 & 0.73 & 0.45 & 0.72 & 1.09 & 1.16 \\
\hline$C D=p(0.05)$ & NS & NS & NS & NS & $0.58 *$ & $0.92 *$ & NS & NS & $0.87 *$ & $1.53 *$ & NS & NS \\
\hline
\end{tabular}

\begin{tabular}{|c|c|c|c|c|c|c|c|c|}
\hline Stages & \multicolumn{4}{|c|}{9 MAP } & \multicolumn{4}{|c|}{ At shooting } \\
\hline $\begin{array}{c}\text { Spacing/ } \\
\text { Fertigation }\end{array}$ & $\mathbf{S}_{1}$ & $\mathbf{S}_{\mathbf{2}}$ & $\mathbf{S}_{\mathbf{3}}$ & Mean & $\mathbf{S}_{1}$ & $\mathbf{S}_{2}$ & $\mathbf{S}_{3}$ & Mean \\
\hline$F_{1}$ & 54.03 & 55.74 & 56.54 & 55.44 & 61.59 & 63.42 & 64.28 & 63.10 \\
\hline$F_{2}$ & 59.46 & 60.63 & 61.84 & 60.64 & 67.38 & 68.55 & 69.84 & 68.59 \\
\hline$F_{3}$ & 62.72 & 64.49 & 64.82 & 64.01 & 70.82 & 72.53 & 73.10 & 72.15 \\
\hline $\mathbf{F}_{4}$ & 60.83 & 63.05 & 63.67 & 62.52 & 68.87 & 71.43 & 72.23 & 70.84 \\
\hline Mean & 59.26 & 60.98 & 61.72 & & 67.17 & 68.98 & 69.86 & \\
\hline & $\mathbf{S}$ & $\mathbf{F}$ & $S$ at $F$ & $F$ at $S$ & $\mathbf{S}$ & $\mathbf{F}$ & $\mathrm{S}$ at $\mathrm{F}$ & $F$ at $S$ \\
\hline SEd & 0.56 & 0.69 & 1.19 & 1.18 & 0.61 & 0.73 & 1.26 & 1.25 \\
\hline $\mathrm{CD}=\mathrm{p}(0.05)$ & $1.60 *$ & $1.46^{*}$ & NS & NS & $1.75^{*}$ & $1.55^{*}$ & NS & NS \\
\hline
\end{tabular}

*Significant at $(\mathrm{P} \leq 0.05)$ NS: Not Significant

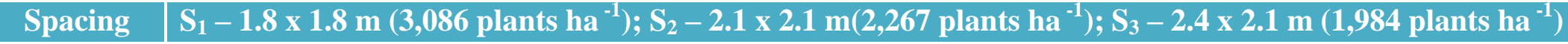

Fertigation $\mathrm{F}_{1}-75 \%$ RDF; $\mathrm{F}_{2}-100 \% \mathrm{RDF} ; \mathrm{F}_{3}-125 \% \mathrm{RDF} ; \mathrm{F}_{4}-150 \%$ RDF (RDF - 150:90:300 g NPK) 
Table.3 Effect of plant density and fertigation on sucker production at different stages of growth of banana cv. Quintal Nendran (AAB)

\begin{tabular}{|c|c|c|c|c|c|c|c|c|c|c|c|c|}
\hline Stages & \multicolumn{4}{|c|}{5 MAP } & \multicolumn{4}{|c|}{7 MAP } & \multicolumn{4}{|c|}{9 MAP } \\
\hline $\begin{array}{c}\text { Spacing/ } \\
\text { Fertigation }\end{array}$ & $\mathbf{S}_{1}$ & $\mathbf{S}_{2}$ & $\mathbf{S}_{\mathbf{3}}$ & Mean & $\mathbf{S}_{1}$ & $\mathbf{S}_{2}$ & $\mathbf{S}_{\mathbf{3}}$ & Mean & $\mathbf{S}_{1}$ & $\mathbf{S}_{2}$ & $\mathbf{S}_{\mathbf{3}}$ & Mean \\
\hline $\mathbf{F}_{1}$ & 1.97 & 2.33 & 2.64 & 2.31 & 3.18 & 3.92 & 4.42 & 3.84 & 4.42 & 5.29 & 5.78 & 5.16 \\
\hline$F_{2}$ & 2.07 & 2.48 & 2.67 & 2.41 & 3.52 & 4.18 & 4.94 & 4.21 & 4.69 & 5.32 & 5.81 & 5.27 \\
\hline $\mathbf{F}_{3}$ & 2.13 & 2.49 & 2.73 & 2.45 & 3.73 & 4.23 & 4.97 & 4.31 & 4.75 & 5.63 & 6.19 & 5.52 \\
\hline $\mathbf{F}_{4}$ & 2.26 & 2.51 & 2.84 & 2.54 & 3.87 & 4.36 & 5.03 & 4.42 & 5.18 & 5.71 & 6.33 & 5.74 \\
\hline Mean & 2.11 & 2.45 & 2.72 & & 3.58 & 4.17 & 4.84 & & 4.76 & 5.49 & 6.03 & \\
\hline & $\mathbf{S}$ & $\mathbf{F}$ & $S$ at $F$ & $F$ at $S$ & $\mathbf{S}$ & $\mathbf{F}$ & $\mathrm{S}$ at $\mathrm{F}$ & $F$ at $S$ & $\mathbf{S}$ & $\mathbf{F}$ & $\mathrm{S}$ at $\mathrm{F}$ & $\mathrm{F}$ at $\mathrm{S}$ \\
\hline SEd & 0.03 & 0.03 & 0.05 & 0.05 & 0.04 & 0.06 & 0.09 & 0.10 & 0.06 & 0.07 & 0.11 & 0.12 \\
\hline $\mathrm{CD}=\mathrm{p}(0.05)$ & $0.07 *$ & $0.06 *$ & NS & NS & $0.10 *$ & $0.12 *$ & NS & NS & $0.15 *$ & $0.14 *$ & NS & NS \\
\hline
\end{tabular}

\begin{tabular}{|c|c|c|c|c|c|c|c|c|}
\hline Stages & \multicolumn{4}{|c|}{ At shooting } & \multicolumn{4}{|c|}{ At harvesting } \\
\hline $\begin{array}{c}\text { Spacing/ } \\
\text { Fertigation }\end{array}$ & $\mathbf{S}_{1}$ & $\mathbf{S}_{2}$ & $\mathbf{S}_{\mathbf{3}}$ & Mean & $\mathbf{S}_{1}$ & $\mathbf{S}_{2}$ & $\mathbf{S}_{\mathbf{3}}$ & Mean \\
\hline $\mathbf{F}_{1}$ & 5.82 & 6.56 & 6.84 & 6.41 & 6.02 & 6.73 & 6.98 & 6.58 \\
\hline $\mathbf{F}_{2}$ & 6.23 & 6.68 & 6.86 & 6.59 & 6.27 & 6.86 & 7.01 & 6.71 \\
\hline $\mathrm{F}_{3}$ & 6.33 & 6.73 & 7.22 & 6.76 & 6.34 & 6.89 & 7.34 & 6.86 \\
\hline $\mathbf{F}_{4}$ & 6.45 & 6.81 & 7.45 & 6.90 & 6.41 & 6.91 & 7.63 & 6.98 \\
\hline Mean & 6.21 & 6.70 & 7.09 & & 6.26 & 6.85 & 7.24 & \\
\hline & $\mathbf{S}$ & $\mathbf{F}$ & $\mathrm{S}$ at $\mathrm{F}$ & $\mathbf{F}$ at $\mathrm{S}$ & $\mathbf{S}$ & $\mathbf{F}$ & $\mathrm{S}$ at $\mathrm{F}$ & $F$ at $S$ \\
\hline SEd & 0.05 & 0.08 & 0.13 & 0.14 & 0.02 & 0.09 & 0.14 & 0.16 \\
\hline$C D=p(0.05)$ & $0.14^{*}$ & $0.17 *$ & NS & NS & $0.07 *$ & $0.19 *$ & NS & NS \\
\hline
\end{tabular}

*Significant at $(\mathrm{P} \leq 0.05)$ NS: Not Significant

Spacing $\quad \mathrm{S}_{1}-1.8 \times 1.8 \mathrm{~m}\left(3,086\right.$ plants $\left.^{-1}\right) ; \mathrm{S}_{2}-2.1 \times 2.1 \mathrm{~m}\left(2,267\right.$ plants ha $\left.^{-1}\right) ; \mathrm{S}_{3}-2.4 \times 2.1 \mathrm{~m}\left(1,984\right.$ plants ha $\left.^{-1}\right)$ Fertigation $F_{1}-75 \%$ RDF; $F_{2}-100 \%$ RDF; $F_{3}-125 \%$ RDF; $F_{4}-150 \%$ RDF (RDF - 150:90:300 g NPK) 
Fig.l. Effect of plant density and fertigation on Absolute Growth Rate (AGR) (cm day $\left.{ }^{-1}\right)$ for pseudostem height and pseudostem girth at 3-5 MAP of banana cv. Quintal Nendran (AAB)

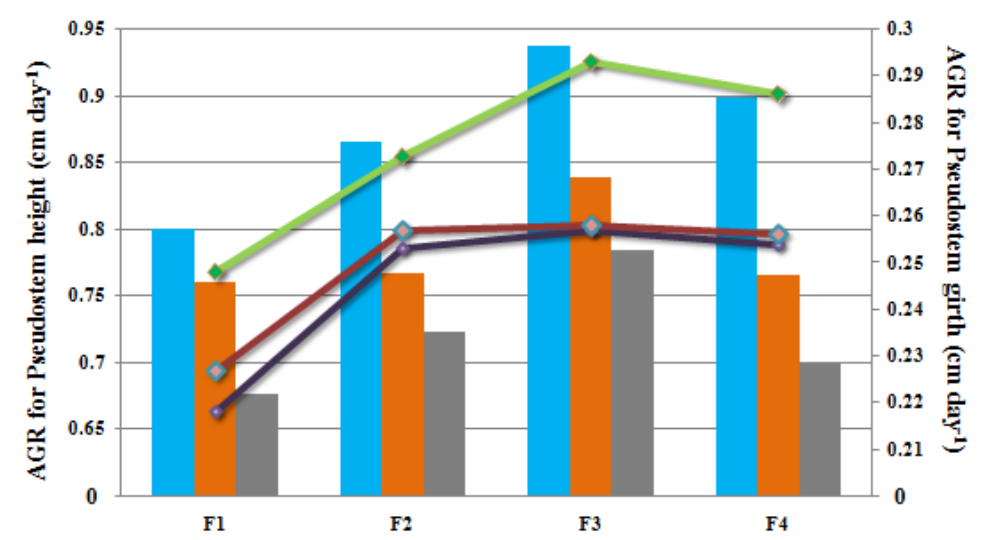

- Pseudostem height S1 $\quad$ Pseudostem height S2 $\quad$ Pseudostem height S3 $\rightarrow$-Pseudostem girth S1 $\quad \leadsto$-Pseudostem girth S2 $\rightarrow$ Pseudostemgirth S3

Fig.3. Effect of plant density and fertigation on Absolute Growth Rate (AGR) (cm day $^{-1}$ ) for pseudostem height and pseudostem girth at 7-9 MAP of banana

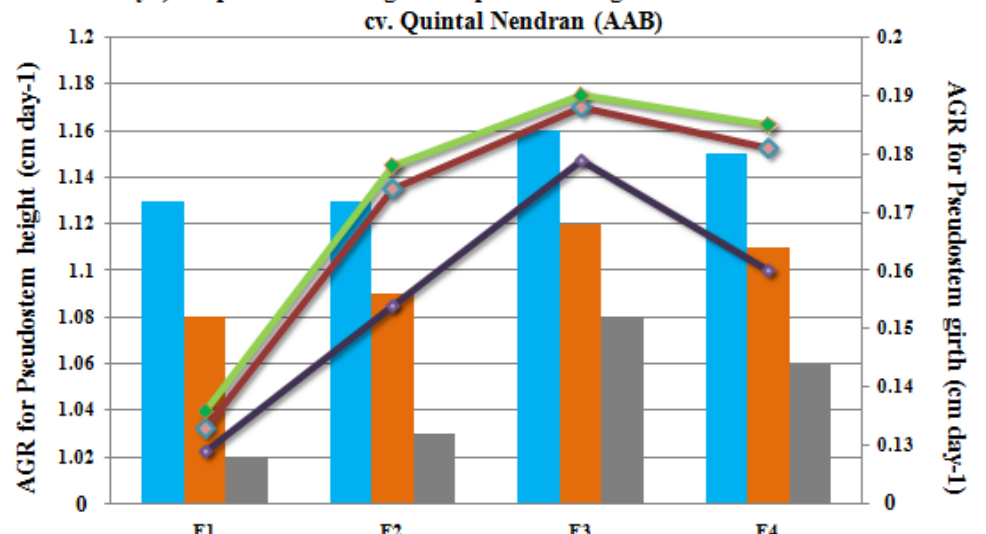

Pseudostem height S1

F4

$\leadsto$ Pseudostem girth S1 $\rightarrow$ Pseudostem girth S2 $\rightarrow$ Pseudostemgirth S3
Fig.2. Effect of plant density and fertigation on Absolute Growth Rate (AGR) (cm day $\left.{ }^{-1}\right)$ for pseudostem height and pseudostem girth at 5 -7 MAP of banana cv. Quintal Nendran (AAB)

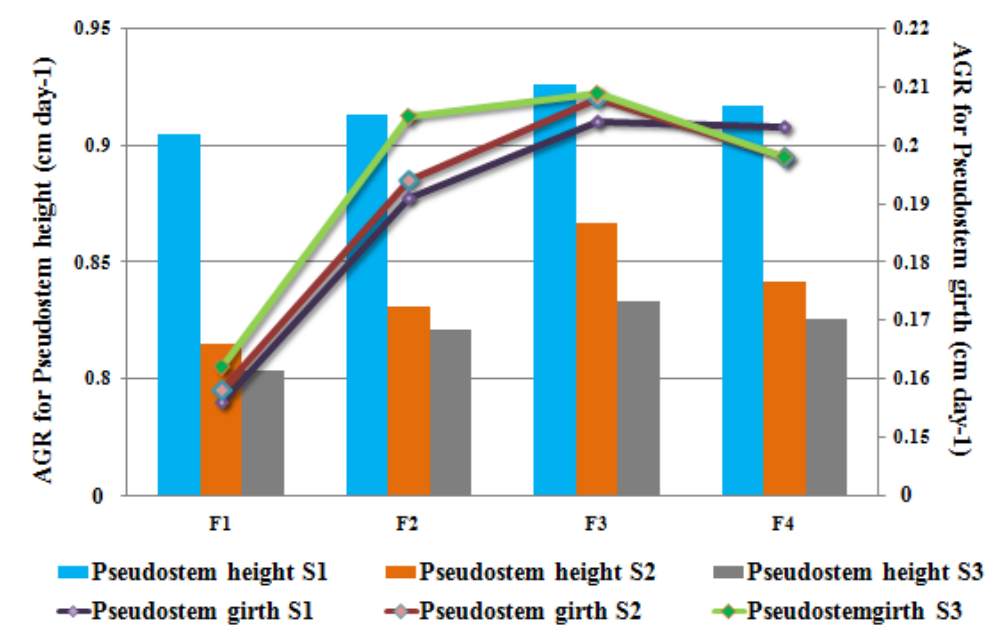

Fig.4. Effect of plant density and fertigation on Absolute Growth Rate (AGR) (cm day ${ }^{-1}$ ) for pseudostem height and pseudostem girth at 9 MAP-shooting of banana

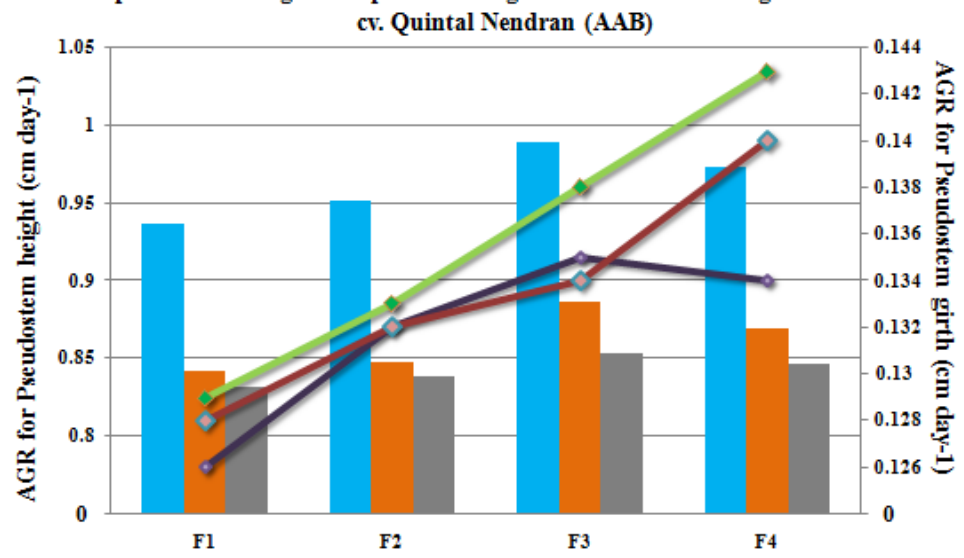

- Pseudostem height S1 $\quad$ Pseudostem height S2 $\quad$ Pseudostem height S3 $\sim$-Pseudostem girth S1 $\rightarrow$ Pseudostem girth S2 $\rightarrow$ Pseudostemgirth S3 
The influence of plant density and fertigation on number of suckers produced per plant at different stages of crop growth in cv. Quintal Nendran is depicted in table 3. At shooting stage, the number of suckers obtained per plant differed significantly. At shooting stage, the number of suckers obtained per plant differed significantly. The spacing level $\mathrm{S}_{3}$ registered highest number of suckers (7.09) per plant, followed by $S_{2}$ (6.70). The lowest number of suckers (6.21) was recorded in $S_{1}$.

The highest number of suckers per plant (6.90) was recorded in $\mathrm{F}_{4}$ treatment, which was on par with $F_{3}(6.76)$ and followed by $F_{2}(6.59)$. The lowest number of suckers per plant (6.41) was recorded in $\mathrm{F}_{1}$ treatment. The interaction effects not differed significantly. Wider spacing $\left(\mathrm{S}_{3}\right)$ and higher levels of fertigation $\left(\mathrm{F}_{4}\right)$ recorded more number of sucker per plant compared to other treatments. Maximum availability of nutrients $\left(\mathrm{F}_{4}\right)$ and ample spacing between plants $\left(\mathrm{S}_{3}\right)$ might have led to development of more number of suckers in these treatments and their interactions. Similar results were also reported by Athani and Hulamani (2000) and Husameldin et al., (2013) in cv. Grand Naine.

The absolute growth rate for pseudostem height exhibited a steady increase with the advancement of age irrespective of the treatments upto $7^{\text {th }}-9^{\text {th }}$ month after planting, later decreased growth rate was noted. The absolute growth rate for pseudostem height was peak during $7^{\text {th }}$ to $9^{\text {th }}$ MAP. The data pertaining to the absolute growth rate (AGR) $\left(\mathrm{cm} \mathrm{day}^{-1}\right)$ for pseudostem height of cv. Quintal Nendran as influenced by planting densities and fertigation at different stages of crop growth are presented in the Figure 1 to 4 . The absolute growth rate pseudostem height exhibited a steady increase with the advancement of age irrespective of the treatments. The AGR for pseudostem height at 9 MAP to shooting stage due to spacing and fertigation differed significantly. In spacing levels, the lowest pseudostem height was recorded in $S_{3}(0.843$ $\left.\mathrm{cm} \mathrm{day}^{-1}\right)$, which was on par with $\mathrm{S}_{2}(0.861 \mathrm{~cm}$ day $\left.^{-1}\right)$. The maximum absolute growth rate $\left(0.963 \mathrm{~cm} \mathrm{day}^{-1}\right)$ was recorded in $\mathrm{S}_{1}$ which was superior over other two levels. The fertigation treatments differed significantly in AGR for pseudostem height, the lowest AGR for pseudostem height was registered in $F_{1}(0.870$ $\left.\mathrm{cm} \mathrm{day}{ }^{-1}\right)$, which was on par with $\mathrm{F}_{2}(0.879 \mathrm{~cm}$ day $\left.^{-1}\right)$, while the highest AGR for pseudostem height $\left(0.909 \mathrm{~cm} \mathrm{day}^{-1}\right)$ was recorded in $\mathrm{F}_{3}$ and it was on par with $F_{4}\left(0.896 \mathrm{~cm} \mathrm{day}^{-1}\right)$. The interaction between spacing and fertigation did not differ significantly.

The absolute growth rate for pseudostem height was highest in closer planting $\left(\mathrm{S}_{1}\right)$ compared to other levels and in interaction effect, it was highest in combination with $\mathrm{F}_{3}$ (125 per cent RDF. Reduced light intensity at ground level with increase in size of the plant canopy and age and solar energy conversion efficiency was maximum in closer spacing and minimum in wider spacing. The results of the present investigation also point out that there was a variation in growth rate in terms of pseudostem height with the age recording more growth rate during initial stages and less during later stages Athani et al., (2009).

The absolute growth rate for pseudostem girth exhibited a steady decrease with the advancement of age irrespective of the treatments upto shooting. The absolute growth rate for pseudostem girth was peak during earlier statge of growth. The AGR for pseudostem girth at 9 MAP to shooting stage due to spacing differed significantly. The maximum absolute growth rate $\left(0.136 \mathrm{~cm} \mathrm{day}^{-1}\right)$ was recorded in $\mathrm{S}_{3}$ and the lowest pseudostem girth was recorded in $S_{1}\left(0.132 \mathrm{~cm} \mathrm{day}^{-1}\right)$, which was on par with $S_{2}\left(0.133 \mathrm{~cm} \mathrm{day}^{-1}\right)$. The heighest AGR for pseudostem girth was recorded in $S_{4}\left(0.139 \mathrm{~cm} \mathrm{day}^{-1}\right)$, which was on par with $S_{3}\left(0.136 \mathrm{~cm} \mathrm{day}^{-1}\right)$ and the lowest AGR for pesudostem girth was recored in $F_{1}$ $\left(0.128 \mathrm{~cm} \mathrm{day}^{-1}\right)$. The interaction between spacing and fertigation not differed significantly. The interaction between spacing and fertigation not differed significantly. The highest absolute growth rate for pseudostem girth in wider spacing $\left(S_{3}\right)$ at highest level of 
fertigation $\left(\mathrm{F}_{3}\right)$ might be due to reduced pseudostem height, which led to more increase in stem girth due to more availability of nutrients compared to other treatments. The decrease in girth in closer spacing $\left(\mathrm{S}_{1}\right)$ was due to increase in pseudostem height of the plant as a resulted of diversion of assimilates to increase in heights at the expense of girth. The present results are in accordance with those Jagirdar et al., (1963) and Gogai et al., (2015).

\section{References}

Athani, S. I., R. Revanappa and P. R. Dharmatti. 2009. Effect of plant density on growth and yield in banana. Karnataka Journal of Agricultural Sciences, 22(1):143-146.

Athani, S.I. and N. C. Hulamani. 2000. Effect of plant density on crop duration and yield in banana cv. Rajapuri (Musa AAB). Karnataka Journal of Agricultural Sciences, 13(1): 116-119.

Gogoi, Sibani, Khangia, Bipin, Baruah and Karthik. 2015. Evaluation on quality parameters and economic feasibility of different banana Musa spp cultivars under Assamese Conditions. Biosci. Biotech. Res. Comm., 8(2): 193-196.

Husameldin, H. M. and Fatima, Y. Gaffer. 2013. Effect of different levels of planting distances, irrigation and fertigation on growth characters of main and ratoon banana crop Cv. Grand Naine. Global Journal of Plant Ecophysiology, 3(2): 104-109.

Mahalakshmi, M. 2000. Water and fertigation management studies in banana cv.
Robusta (AAA) under normal planting and high density planting systems. Ph.D. (Hort.) Thesis. Tamil Nadu Agricultural University, Coimbatore.

Naik, M. H. 2016. Studies on high density planting, fertigation and postharvest chemical treatments in banana (Musa acuminate L.) cv. Grand Naine. Ph.D (Fruit Science) Thesis, submitted to Dr. Y.S.R. Horticultural University, Rajendranagar.

Nankinga, C. K., E. Magara, C. S. Gold, R.S. Kawuki, R. Erima, P. Ragama, S. R. Gowen and W. Tushemereirwe. 2005. Respoanse of East African Highland bananas to plant density in Uganda. Proceedings of African Crop Science Conference, 7: 1183-1186.

NHB. 2016. Banana area, production and productivity. http://www.nhb.gov.in

Pralhad, G. A. 2014. Comparative performance of water soluble and routinely used fertilizer in banana cv. Grand naine under drip irrigation. Ph.D (Fruit Science) Thesis, Navsari Agricultural University, Navsari.

Salvador, A., T. Sanz and S. M. Fiszman. 2007. Changes in colour and texture and their relationship with eating quality during storage of two different dessert bananas. Post-harvest Biology and Technology, 43: 319- 325.

Sarrwy, S. M. A., E. M. A. Mostafa and H. S. A. Hassan. 2012. Growth, yield and fruit quality of Williams Banana as affected by different planting distances. International Journal of Agricultural Research, 7 (5): 266-275.

\section{How to cite this article:}

Sindhupriya, V., J. Auxcilia and Soorianathasundaram, K. 2018. Effect of Planting Density and Nutrient Requirement on Growth and Development of Banana cv. Quintal Nendran (AAB). Int.J.Curr.Microbiol.App.Sci. 7(11): 3060-3068. doi: https://doi.org/10.20546/ijcmas.2018.711.351 